\title{
The expression of apoptosis inducing factor (AIF) is associated with aging-related cell death in the cortex but not in the hippocampus in the TgCRND8 mouse model of Alzheimer's disease
}

\author{
Wenfeng $\mathrm{Yu}^{1,2}$, Mathilde Bonnet ${ }^{2}$, Mark Farso ${ }^{2}$, Keran $\mathrm{Ma}^{3}$, Jean-Guy Chabot ${ }^{2}$, Elisabeth Martin ${ }^{4}$, Alicia Torriglia ${ }^{4}$,
} Zhizhong Guan ${ }^{1,5}$, JoAnne McLaurin ${ }^{3}$, Rémi Quirion ${ }^{2}$ and Slavica Krantic ${ }^{2,4^{*}}$

\begin{abstract}
Background: Recent evidence has suggested that Alzheimer's disease (AD)-associated neuronal loss may occur via the caspase-independent route of programmed cell death (PCD) in addition to caspase-dependent mechanisms. However, the brain region specificity of caspase-independent PCD in AD-associated neurodegeneration is unknown. We therefore used the transgenic CRND8 (TgCRND8) AD mouse model to explore whether the apoptosis inducing factor (AIF), a key mediator of caspase-independent PCD, contributes to cell loss in selected brain regions in the course of aging.

Results: Increased expression of truncated AIF (tAIF), which is directly responsible for cell death induction, was observed at both 4- and 6-months of age in the cortex. Concomitant with the up-regulation of tAIF was an increase in the nuclear translocation of this protein. Heightened tAIF expression or translocation was not observed in the hippocampus or cerebellum, which were used as AD-vulnerable and relatively AD-spared regions, respectively. The cortical alterations in tAIF levels were accompanied by increased Bax expression and mitochondrial translocation. This effect was preceded by a significant reduction in ATP content and an increase in reactive oxygen species (ROS) production, detectable at 2 months of age despite negligible amounts of amyloid-beta peptides (A $\beta$ ).
\end{abstract}

Conclusions: Taken together, these data suggest that AIF is likely to play a region-specific role in AD-related caspaseindependent PCD, which is consistent with aging-associated mitochondrial impairment and oxidative stress.

Keywords: Programmed cell death (PCD), Caspase-independent, Amyloid-beta peptide, Oxidative stress, Brain

\section{Background}

Alzheimer's disease (AD) is an age-related neurodegenerative disorder, histologically characterized by the extracellular deposition of amyloid $\beta$ peptides $(\mathrm{A} \beta$ ) and the intracellular accumulation of hyperphosphorylated tau. Numerous in vitro and in vivo studies have provided evidence for a key role of $A \beta$ in $A D$ [1,2]. $A \beta$-associated neurodegeneration involves cerebral cell death, but the underlying mechanisms remain largely unknown. Animal models of $\mathrm{AD}$ offer a unique opportunity to study the

\footnotetext{
* Correspondence: slavica.krantic@crc.jussieu.fr

${ }^{2}$ Department of Psychiatry, Douglas Mental Health University Institute (DMHUI), McGill University, Verdun Montréal, Québec H4H 1R3, Canada

${ }^{4}$ Centre de Recherche des Cordeliers, UMRS872, Paris, France

Full list of author information is available at the end of the article
}

mechanisms involved in AD-related neurodegeneration, particularly the contribution of specific types of cell death during neuronal demise. Although neuronal death cannot be reproduced in all mouse models of $A D$, brain regions of some transgenic mice (e.g. PS1xAPP and TgCRND8) have been reported to demonstrate an age-dependent vulnerability, with the cortex and hippocampus being affected the earliest [3-5].

Neurodegeneration in age-associated dementia of the $\mathrm{AD}$ type is thought to involve neuronal cell loss by programmed cell death (PCD) [6,7]. Various caspases have been recognized as important mediators of neuronal PCD in AD [8] by classical caspase-dependent apoptosis. Several studies have shown the presence of activated 
caspases and the resulting caspase-cleaved substrates, including tau and amyloid precursor protein (APP) in post-mortem human $\mathrm{AD}$ brains and animal models [9-15]. However, accumulating evidence also points to the involvement of caspase-independent mechanisms in neuronal PCD [16-18]. In particular, apoptosis-inducing factor (AIF) is considered to play a central role among key effectors involved in caspase-independent neuronal cell death [19-21]. Consistently, we have recently reported the increased nuclear translocation of AIF in the hippocampus and cortex of post-mortem human tissues derived from AD patients [22]; this being indicative of caspaseindependent PCD via AIF.

The mitochondrial flavoprotein AIF is synthesised in the cytoplasm as a $\sim 67 \mathrm{kDa}$ precursor. Its maturation involves a proteolytical cleavage of the precursor to a ubiquitously expressed $\sim 62 \mathrm{kDa}$ form [20]. Mature AIF is imbedded into the inner mitochondrial membrane where it is involved in organizing and/or maintaining the structural integrity of the respiratory chain complex-I [23,24]. Indeed, deficiency in AIF expression is associated with reduced complex-I activity and decreased ATP production [24]. Upon pathological mitochondrial permeabilization, AIF is further processed to $\mathrm{a} \sim 57 \mathrm{kDa}$ truncated form (tAIF) $[25,26]$, then released from mitochondria and translocated to the nucleus where it participates in the induction of caspase-independent PCD [27-29].

Interestingly, Harlequin $(\mathrm{Hq})$ mutant mice with reduced expression of AIF display decreased oxidative phosphorylation in specific neuronal populations [24]. The reduced expression of AIF in Hq mice is correlated with a lowered expression of mitochondrial complex-I, together with signs of oxidative stress linked to increased reactive oxygen species (ROS) production in dying neurons [24,30,31]. Thus, mitochondrial dysfunction, seen in the course of rodent brain aging, is strikingly similar to that observed in AIF-deficient neurons, suggesting a possible relationship between age-related decreases in AIF expression, mitochondrial impairment and neuronal death. This hypothesis is in line with the fact that mitochondrial injury in $\mathrm{Hq}$ mice, due to low AIF expression, precedes the onset of neurodegeneration [32].

Moreover, although AIF is ubiquitously expressed in the rodent brain, we observed a brain region-specific gradient of distribution in the normal rat brain [33]. Such contrasting levels of AIF expression indicated that AIF-induced PCD may be region specific. To explore this possibility, we investigated AIF-related cell death in brain regions vulnerable to $\mathrm{AD}$-like pathology in the transgenic mouse model, TgCRND8 (Tg), at 2, 4, 6-7 and 9 months of age. These selected ages correspond to pre-plaque, plaque burden, overt AD-like pathology and advanced AD-like pathology stage, respectively [34]. The cortex and hippocampus were compared because they are the most affected regions in $\mathrm{Tg}$ mice [35], whereas the cerebellum was chosen as a relatively spared control region. Overall, our data suggest that among the vulnerable brain regions, AIF is involved in AD-associated PCD in the cortex but not in the hippocampus.

\section{Results}

Accumulation of $A \beta$ in the cortex and hippocampus of $\mathrm{Tg}$ mice is accompanied by signs of oxidative stress

We examined the $A \beta$ load as a function of age in the cortex, hippocampus and cerebellum of $\mathrm{Tg}$ mice. Using brain region and age as between-subject factors, a two-way ANOVA analysis of total A $\beta$ levels showed significant brain region and age interaction $(\mathrm{F}[6,36]=7.604, \mathrm{p}<$ 0.001). Multiple comparisons showed significant regional differences in total $A \beta$ levels, with higher levels in the cortex compared to hippocampus $(\mathrm{p}=0.025)$ and cerebellum $(\mathrm{p}=0.001)$

We next investigated the levels of both $A \beta_{1-40}$ and $A \beta_{1-42}$ as a function of age and brain region. In all three brain regions of 2- and 4-month-old mice, the level of $A \beta_{1-40}$ (Figure 1A) and $A \beta_{1-42}$ (Figure 1B) was low, only reaching the limit of detection at 2 months while remaining relatively low at 4 months. The difference in the level of expression of either peptide was not significant between these two ages in any of the brain regions (Figure. $1 \mathrm{~A}, \mathrm{~B}$ ). In contrast, $\mathrm{A} \beta_{1-40}$ (Figure $1 \mathrm{~A}$ ) and $A \beta_{1-42}$ (Figure $1 B$ ) were significantly increased in older (7- and 9-month-old) animals. For $A \beta_{1-40}$, the observed difference in the cortex and hippocampus was significant for 6-7-month-old animals in comparison to younger (either 2- or 4-month-old) mice. The level of $A \beta_{1-42}$ in the hippocampus (but not in the cortex) was significantly different between 6-7-month-old mice and 2- or 4month-old groups (Figure 1B). In all brain regions, including the cerebellum, the difference was significant for the comparison between 9-month-old animals and all other ages for both $A \beta_{1-40}$ and $A \beta_{1-42}$ (Figure $1 A$ and $B$ ).

Oxidative stress has been proposed to increase with $A \beta$ peptide accumulation. We therefore undertook a parallel assessment of oxidative stress, via the quantification of ROS. The alterations seen in the cortex indicated the establishment of oxidative stress in the course of brain aging (Figure 2A). Interestingly in this region, ROS production was significantly higher in $\mathrm{Tg}$ than in non-Tg mice as early as 2 months of age. Moreover, the difference in ROS production between the two genotypes was significant in all age groups, except for the 4-month old mice (Figure 2A). Comparison between cortical ROS levels among transgenic animals indicated a significant increase in the course of aging (except for the 4-month-old group) when 2-month-old $\mathrm{Tg}$ mice were taken as a reference value (Figure 2A). 


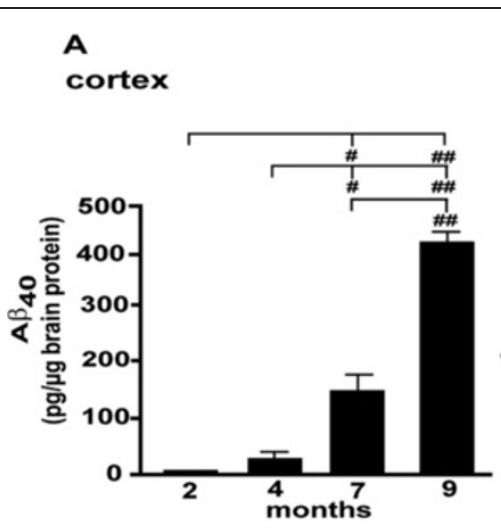

hippocampus

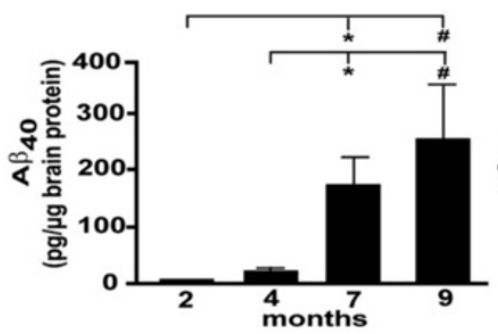

cerebellum

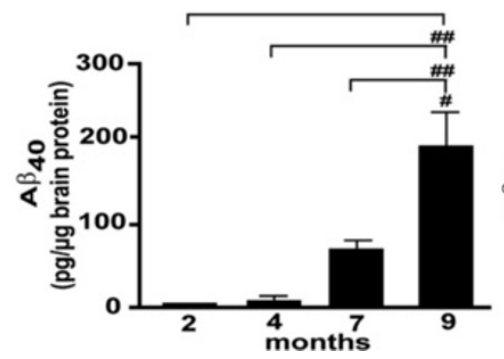

B

cortex

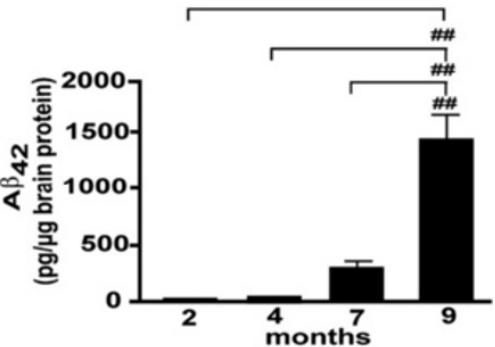

hippocampus

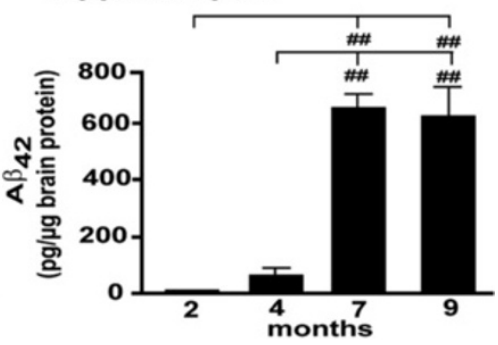

cerebellum

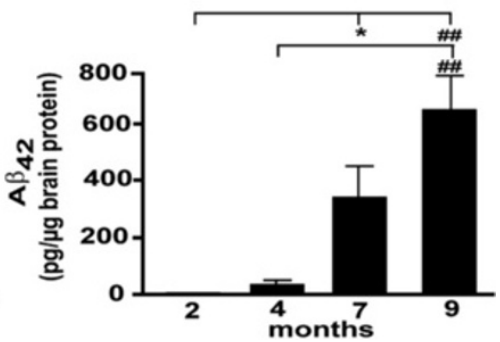

Figure 1 Expression of different $\mathbf{A} \boldsymbol{\beta}$ species in the Tg mice. (A): The levels of total $A \beta_{1-40}$ were assayed by ELISA in cortical, hippocampal and cerebellar extracts of $\mathrm{Tg}$ mice at indicated ages. (B): The levels of total $A \beta_{1-42}$ were determined by ELISA in cortical, hippocampal and cerebellar extracts of Tg mice at indicated ages. ${ }^{*} \mathrm{P}<0.05$; $\# \mathrm{P}<0.01$; \#\#P $<0.001$; \#\#P $<0.0001$.

In the hippocampus of $\mathrm{Tg}$ and non-Tg mice a significant difference in ROS levels was seen between 4- and 6month-old groups (Figure 2A). In contrast, in 2- and 9month-old groups, the difference between $\mathrm{Tg}$ and non-Tg mice was not significant (Figure 2A). However, comparing the level of ROS between the ages in transgenic animals revealed that it was significantly higher in all ages when compared to 2-month-old Tg mice (Figure 2A). No significant difference was observed between either genotype or age in the cerebellum (Figure 2A), confirming this brain region as a negative control.

To further explore the establishment of oxidative stress in the course of aging in the three brain regions, we studied the level of expression of neuronal nitric oxide synthase (nNOS). A moderate increase in expression of nNOS was observed between 2- and 9-month-old mice in both cortex and hippocampus but the difference was only statistically significant in the hippocampus (Figure 2B). In contrast to the cortex and hippocampus but in agreement with ROS levels, no difference was found in the cerebellum (Figure 2B).

As mitochondria are known to be causally involved in the establishment of oxidative stress and a target of $A \beta$ toxicity, we aimed to further investigate function by comparing the level of ATP production between $\mathrm{Tg}$ and non-Tg mice. These experiments revealed a slightly decreased production of ATP in vulnerable areas (cortex and hippocampus) of most age groups of $\mathrm{Tg}$ mice versus agematched non-Tg. However, the difference was greater at the younger stages and was only significant in the cortex of the 2-month-old group (Figure 3). All other comparisons, and specifically those for the cerebellum, indicated a similar level of ATP production between the two genotypes and age groups (Figure 3 ). 


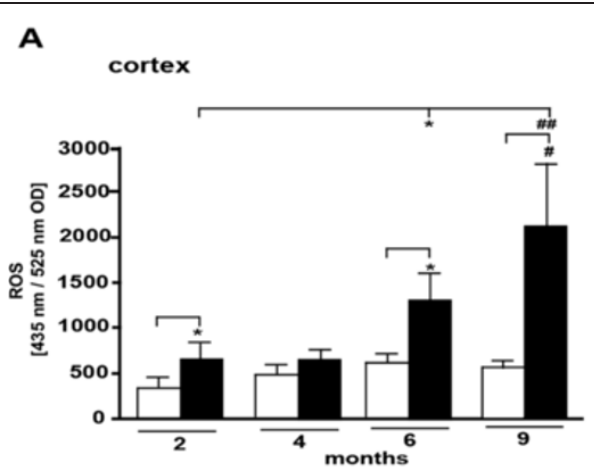

\section{B}

cortex

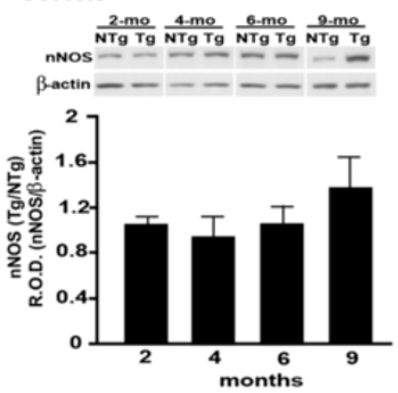

hippocampus
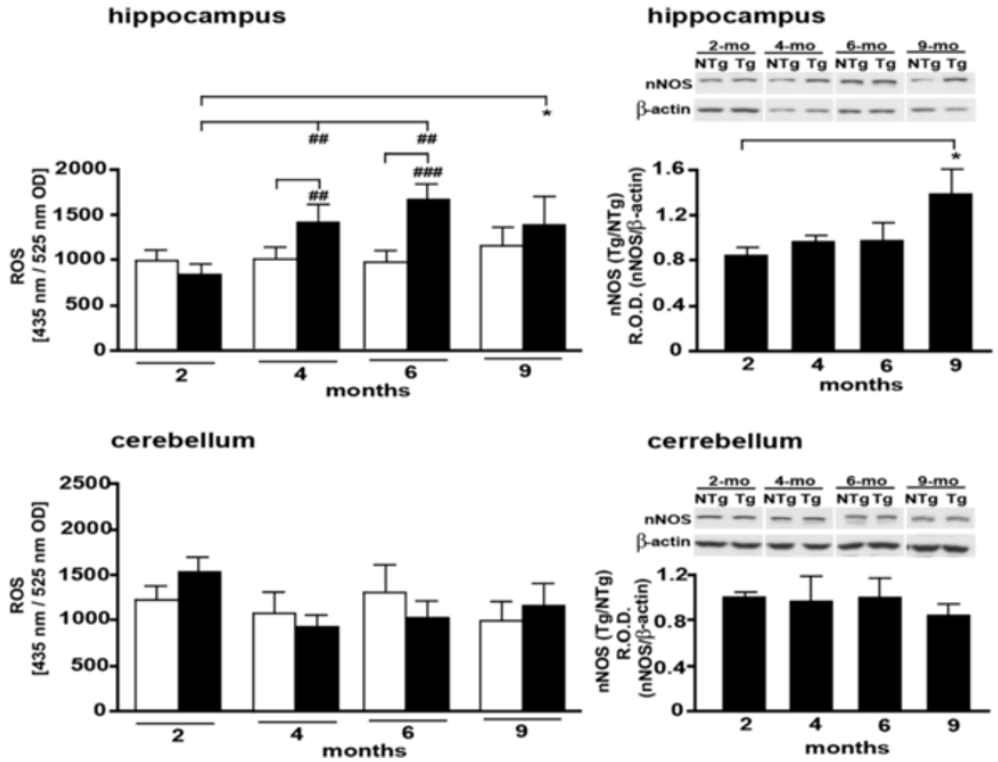

Figure 2 Markers of oxidative stress in the Tg mice. (A): ROS expression in cortex, hippocampus and cerebellum of Tg mice as compared to their non-Tg littermates of the indicated ages. White- and black bars depict the values determined for non-Tg and Tg mice, respectively. (B): nNOS quantification in cortex, hippocampus and cerebellum of Tg mice as compared to their non-Tg littermates of the indicated ages. Equal protein loading was confirmed by detection of $\beta$-actin. ${ }^{*} \mathrm{P}<0.05$; \#P $<0.01$; \#\#P $<0.001$; \#\#\#P $<0.0001$.

Expression of cell death markers in the cortex and hippocampus of aging $\mathrm{Tg}$ mice

To assess neuronal death, we focused on indirect markers of cell death because it is extremely difficult to directly quantify the number of dead neurons in $\mathrm{AD}$ mouse models [37-39]. In agreement, our attempts to quantify neuronal death by TUNEL assay didn't reveal significant differences between genotypes (data not shown) in spite of the fact that loss of specific sub-types of neurons has been reported by 6 months of age in TgCRND8 [3,40]. In order to assess the extent of cell death in the brain of $\mathrm{Tg}$ mice, we determined the levels of the universal proapoptotic protein, Bax, and the induction of cyclin D1, the latter is considered to be an early commitment step in neuronal cell death.

The universal involvement of this $\mathrm{BCl} 2$ family member, Bax, in cell death has been largely demonstrated [41]. Moreover, Bax has recently been shown to be directly involved in $A \beta$ toxicity to neurons [36]. In our experiments, the cortical expression of Bax is significantly increased in 4- and 6-7-month-old Tg animals when compared to the 2-month-old group (Figure 4A). Since it has been reported that gender may impact the expression of $\mathrm{BCl} 2$ family members and because we used sex-balanced groups of mice in our study, we investigated whether the level of Bax expression differed between males and females. We found no significant difference for either genotype (nTg $\mathrm{p}=0.42 ; \operatorname{Tg} \mathrm{p}=0.46$ ). Because the death-inducing activity of Bax relies on its translocation from cytoplasm to mitochondria [41,42], we assessed the distribution of Bax between these two cellular compartments by performing the sub-cellular fractionation experiments. Our data show increased mitochondrial Bax translocation in 4- and 6 months aged TgCRND8 mice (Figure 4B), which is compatible with cell death induction. By contrast, there was no significant difference between the level of active Bax expression in cerebellum and hippocampus (Figure 4A). However, in contrast to cerebellum, hippocampus displayed 


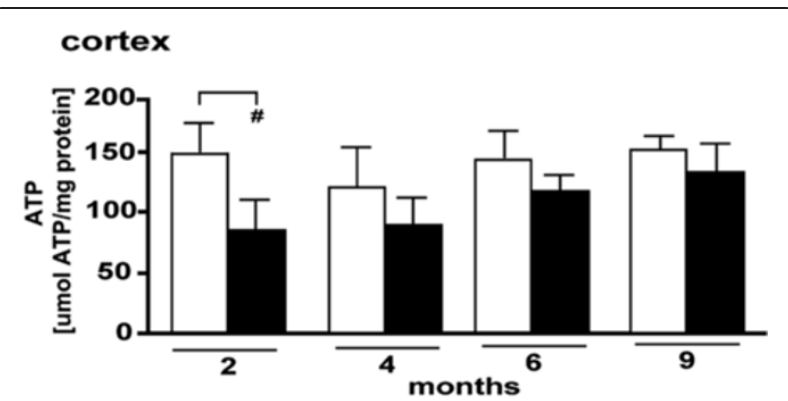

hippocampus

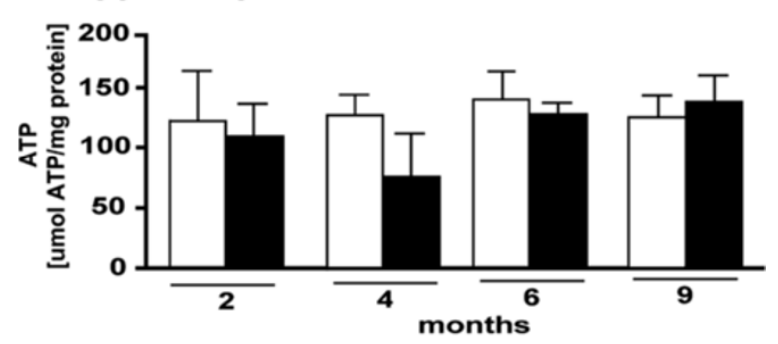

cerebellum

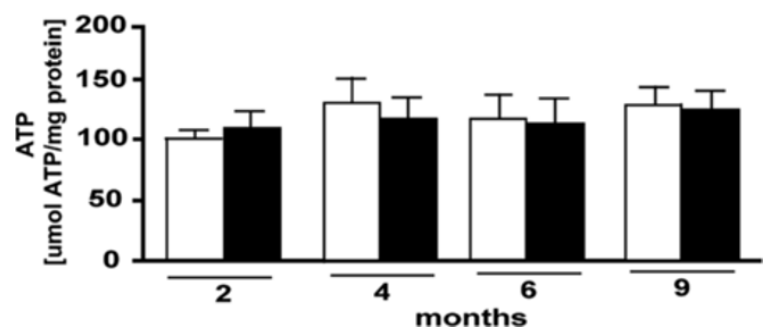

Figure 3 ATP levels in the Tg mice and corresponding non-Tg littermates at indicated ages. ATP is expressed in $\mu \mathrm{mol}$ ATP/mg protein. ${ }^{*} P<0.05$; \#P $<0.01$; \#\# $<0.001$; \#\#\# $<0.0001$.

an increasing, age-dependent trend of active Bax expression where only the difference between the youngest ( 2 months) and oldest (9 months) groups was significant (Figure 4A).

The induction of cyclin D1 is considered to precede neuronal death in some pathological paradigms. For example, cyclin D1 induction is related to excitotoxicity, which is known to be tightly associated with oxidative stress and is correlated with increasing $A \beta$ levels $[43,44]$. Moreover, cyclin D1 induction has been involved in neuronal death, as shown in hippocampal $[45,46]$ and cortical $[47,48]$ neurons, in vitro, as well as animal and human AD post-mortem tissues $[49,50]$. In the current study, no difference was noted with age in any of the regions studied (Figure 4C). These results indicate that the strength of the cell death-inducing capacity of $\mathrm{A} \beta$, as reflected by increased Bax levels of expression and mitochondrial translocation, which irreversibly direct cells to PCD, may be non-permissive for cyclin D1 induction. Consistently, cyclin D1 induction is generally considered as a part of the cell defence response to initially mild (reparable) DNA damage related to oxidative stress [51].
Cell death in the cortex, but not in the hippocampus, is associated with AIF in aging $\mathrm{Tg}$ mice

The cortical expression of tAIF ( $57 \mathrm{kDa})$ was similar at 4- and 6-months-of-age and significantly higher than in the youngest and the oldest groups studied (Figure 5A). The expression of tAIF was not different between the age groups in either hippocampus or cerebellum (Figure $5 \mathrm{~B}$ and $5 \mathrm{C}$, respectively). Interestingly, the level of expression of the mitochondrial form $(62 \mathrm{kDa})$ was significantly higher in the hippocampus of 6-month-old Tg mice compared with the other ages studied (i.e. 2, 4 and 9 months) (Figure 5B). The $62 \mathrm{kDa}$ form was not altered with age in either cortex or cerebellum relative to non- $\mathrm{Tg}$ littermate levels (Figure $5 \mathrm{~A}$ and $5 \mathrm{C}$, respectively). However, independently of the genotype, the level of expression of the $62 \mathrm{kDa}$ form appears higher in the cerebellum (Figure $5 \mathrm{C}$ : western blot scan) compared to the other two regions (Figure 5A and 5B: relevant western blot scans), which is in agreement with a general view that this brain region displays lower vulnerability to $\mathrm{AD}$ compared to the cortex and hippocampus.

To confirm the biochemical data pointing to the involvement of AIF in cell death in the cortex of 4- and 6month-old Tg mice, we assessed the histological signature of AIF nuclear translocation and cell death induction [22] using immunohistochemistry. We examined the population of cells in which nuclear exclusion from AIF staining is no longer visible. In agreement with the biochemical data, a low number of cells without nuclear exclusion from AIF staining was seen in the cortex of 2-month-old mice (Figure 6A and 6B), with similar low numbers in 9month-old mice (Figure 6G and $6 \mathrm{H}$ ) irrespective of their genotype (non-Tg: Figure 6A and 6G and Tg: Figure 6B and $6 \mathrm{H})$. In contrast, at 4 and 6-7 months of age, more cells with nuclear exclusion from AIF staining were apparent in $\mathrm{Tg}$ (Figure 6D and 6F) than in non-Tg (Figure 6C and $6 \mathrm{E}$ ) mice. The occurrence of nuclear translocation of AIF has been further confirmed with higher resolution by using confocal microscopy (Figure 7). Moreover, the analysis of the co-localization profiles of AIF (red) and DAPIstained nuclei (blue) clearly indicate the presence of AIF in the nuclear compartment of cells in which AIF has translocated to the nucleus (Figure 7B).

\section{Discussion}

The main finding of this study showed that the cleavage of AIF into cell death-inducing tAIF increased in the course of aging and $A \beta$ accumulation selectively in the cortex of the Tg mouse model of AD studied. Moreover, the age-dependent increase in tAIF was not found in other vulnerable (hippocampus) or relatively spared (cerebellum) brain areas further pointing to the specificity of the observed alterations in the cortex. These results are the first to indicate the contribution of the key mediator of caspase-independent programmed cell death, AIF, to 


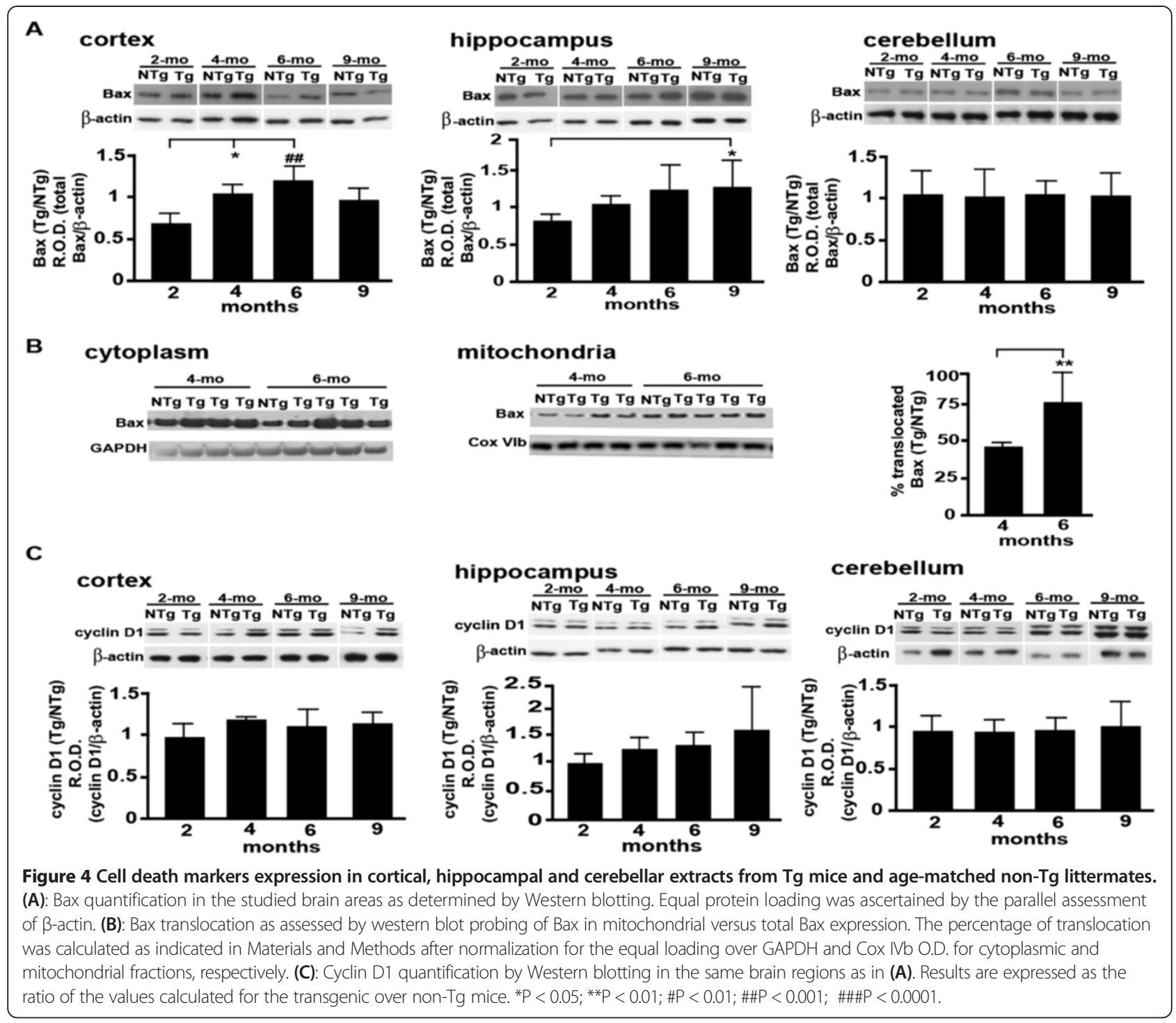

the cell loss associated with age-related progression in a model of AD-like pathology.

Furthermore in our study, cortical oxidative stress in $\mathrm{Tg}$ mice was found to occur as early as the pre-plaque stage (i.e. 2 months), thus greatly preceding the onset of plaque burden (3-4 months) $[34,40]$ and cell loss (6-7 months) $[3,40]$. These findings validate our methodological approaches, as they are in agreement with previously published data in other AD mouse models demonstrating the relationship between oxidative stress, $A \beta$ and $A \beta$ plaque accumulation [52-56]. Interestingly, the first signs of mitochondrial dysfunction, including signs of oxidative stress such as increased ROS production, coincide with the intracellular accumulation of $A \beta$ and continue to accumulate with further increases in $A \beta$ and its deposition into plaques in Thy-1 APP mice [54]. In addition, our results point to a higher $A \beta$ load in the cortex than in the hippocampus and cerebellum of TgCRND8 mice. Moreover, despite a general trend towards the up-regulated production of ROS in both hippocampus and cortex of the youngest (2-month-old) mice, this increase was only significant in the cortex. These results are in line with the recently published data in APP/ PS1 mice where oxidative stress is specifically increased in the cortex before evidence of plaque burden [53].

Besides, the increase in the level of ROS was accompanied by decreased ATP production only in the cortex of the youngest (i.e. 2 months) age group studied, further suggesting early mitochondrial dysfunction in this brain region. These results may not be surprising since creatine levels have been reported to rise with age, and this might function to buffer ATP production [57]. Remarkably, the study of the mitochondrial proteome has recently identified an early alteration in expression of more than 20 proteins, among others involved in oxidative stress and apoptosis, specifically in the cortex of another mouse model of Alzheimer's disease [52]. 


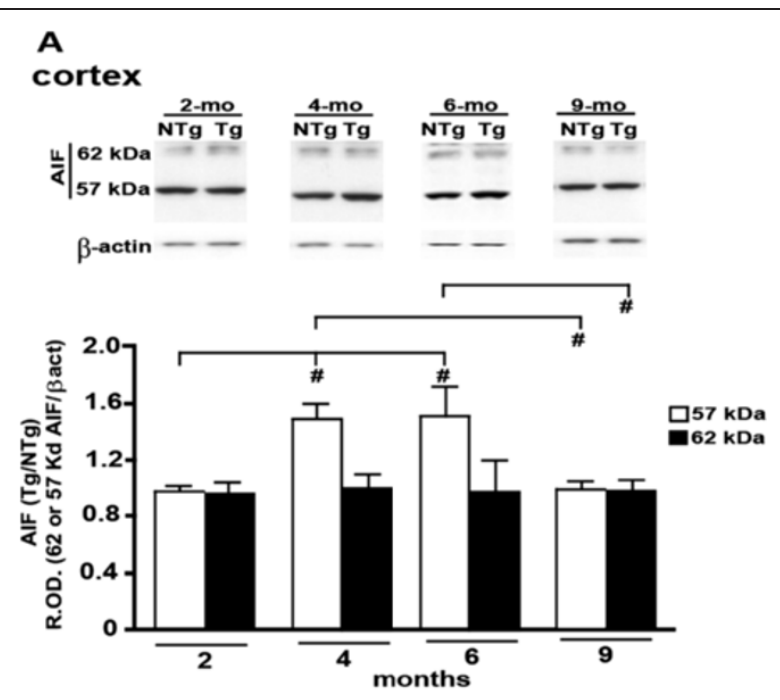

B

\section{hippocampus}

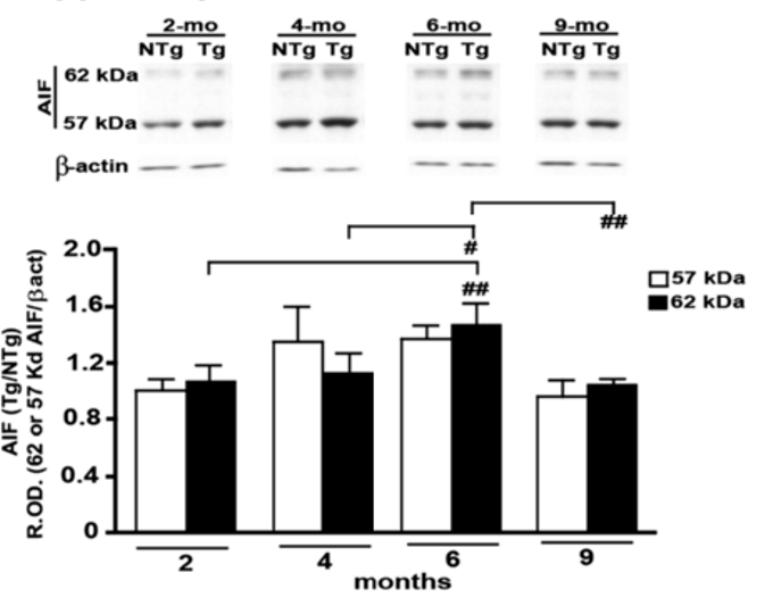

C

cerebellum
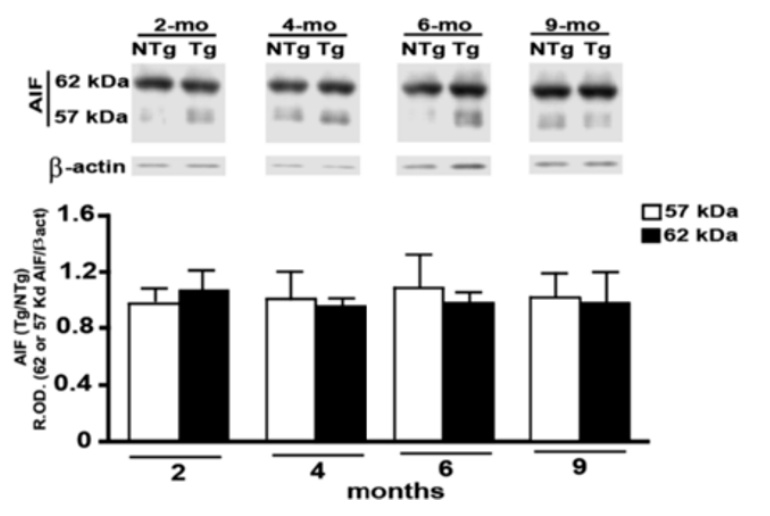

Figure 5 AIF expression in cortical (A), hippocampal (B) and cerebellar (C) extracts from Tg mice and their age-matched non-Tg littermates at indicated ages. Both mitochondrial $(62 \mathrm{kDa}$, white bars) and tAIF (57 kDa, black bars) forms of AIF were studied. Equal protein loading was confirmed by detection of $\beta$-actin. Results were expressed as the ratio of the values calculated for the transgenic over non-Tg mice. ${ }^{*} \mathrm{P}<0.05$; \#P $<0.01$; \#\#P $<0.001$; \#\# $\quad$ < 0.0001 .

The signs of mitochondrial dysfunction observed in our study preceded the increased production of tAIF and its nuclear translocation, both of which were augmented in cortices of mid-aged (4- and 6-month-old) Tg mice. Taken together, these data may suggest a causal relationship between mitochondrial impairment/oxidative stress and AIF-mediated caspase-independent PCD in this transgenic $\mathrm{AD}$ mouse model. In addition, these findings confirm and extend previous reports on the causal relationship between early mitochondrial dysfunction and multiple AD-associated cell death pathways including caspasedependent apoptosis and autophagic pathways [52,56,58].

Despite the observed genotypic differences in ROS levels, the production of ATP was similar between transgenic and non-Tg mice during aging (excluding 2month-old transgenics). Previous studies have described differences in distinct ROS scavenging capacity as well as metabolic and intracellular signalling between the cortex and hippocampus $[52,55,59,60]$. Therefore, the differential sensitivity of mitochondrial ATP production and increased ROS between these two regions reported herein may be associated with their respective level of expression of AIF. In agreement with this hypothesis, our previous study revealed significant differences in the level of AIF expression between brain regions of the rodent brain [33]. Furthermore, low level of AIF expression in Harlequin mice has been linked to mitochondrial respiratory chain dysfunction [24] and AIF has been implicated in ROS production [61]. Therefore, it is plausible that the tissue level of AIF may be related to the degree of $A \beta$-induced oxidative stress and subsequent AIF-mediated cell death.

Age-related cell death in Tg mice was demonstrated in this study by increased levels of cortical tAIF and Bax in the mid-aged groups (4- and 6-month old). However, in the oldest group (9-month-old Tg mice) AIF-mediated cell death was not evident, as indicated by the absence of increased tAIF and Bax. This apparent paradoxical observation may be related to the limited, yet still significant, neuronal loss observed in our model, starting by $6-7$ months of age $[3,40]$.

Cell death in the hippocampus has been documented at 6 months of age in TgCRND8 mice [40]. Interestingly in this study, the hippocampal level of Bax was not increased before 9 months and no significant age-dependent increase was seen in the level of tAIF, suggesting that 


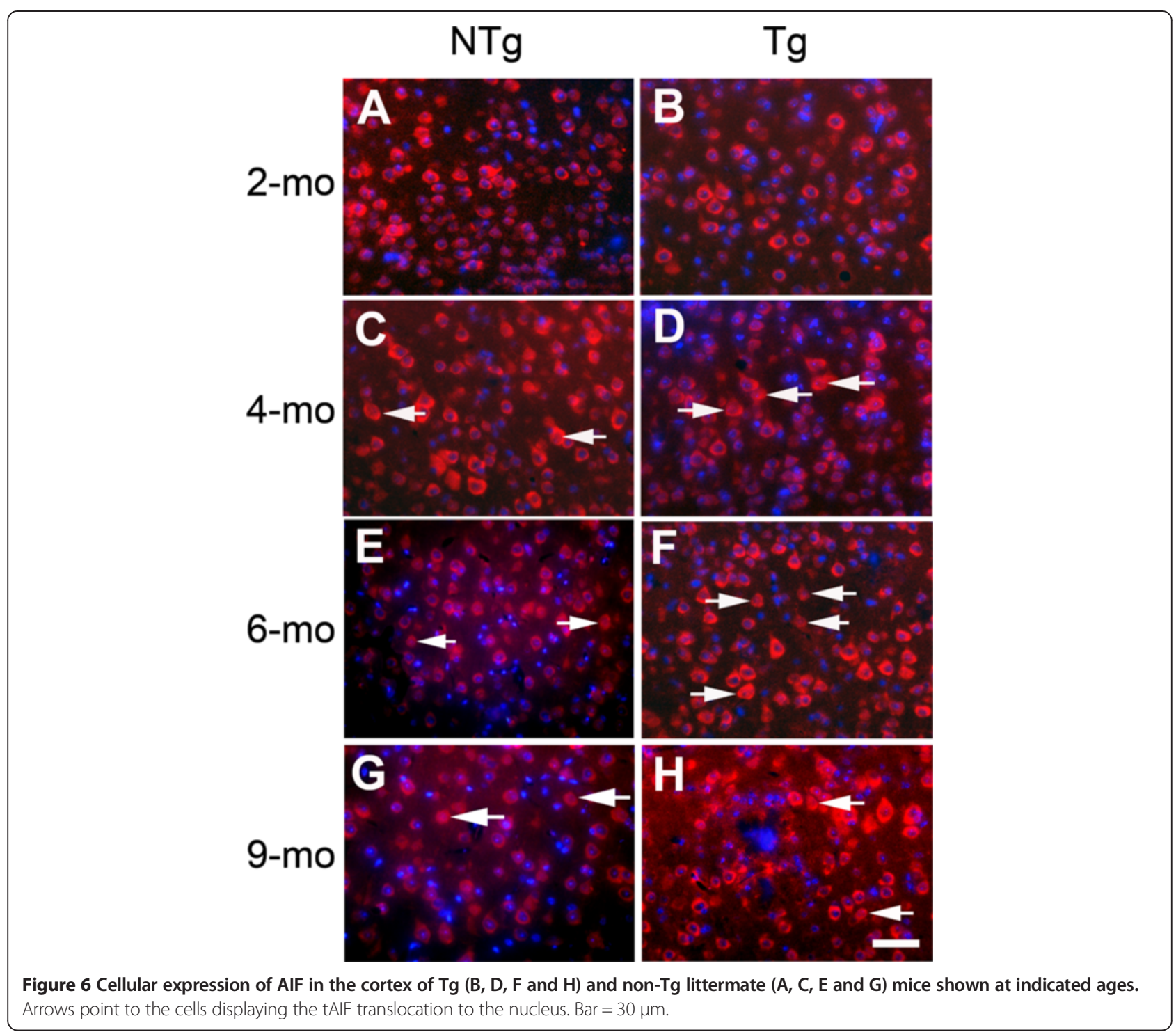

cell death does not involve AIF and is Bax-independent, at least up to 9 months of age. In the hippocampus of the two mid-aged groups, the absence of deleterious effects (despite high levels of ROS) is suggested to be the result of compensated production of ATP, which may be related to the increased expression of the mitochondrial, $62 \mathrm{kDa}$, form of AIF. An increased expression of this form of AIF may provide more efficient respiratory chain function due to, at least in part, more efficient complex I and III function [24].

Cyclin D1 expression, used here as an early marker of neuronal cell death, was similarly expressed between different age groups in all brain regions. Although cyclin $\mathrm{D} 1$ induction has been associated with $\mathrm{A} \beta$-induced cell death, in vitro and in human post-morten $\mathrm{AD}$ brain tissues [45,48-50], the data are much less conclusive regarding the relationship of cyclin $\mathrm{D} 1 / \mathrm{A} \beta$ in $\mathrm{AD}$ mouse models $[50,62]$.

\section{Conclusion}

Overall, our data suggest that in the course of aging, AIF may play a different role in $\mathrm{AD}$-related caspase-independent $\mathrm{PCD}$, depending on the brain region and relative contribution of multiple PCD pathways to neurodegeneration. Since caspase-dependent apoptosis has been reported to occur both in the cortex and in the hippocampus [58], future therapeutic strategies should take into the account a multi-therapeutic approach targeting both caspasedependent and caspase-independent PCD.

\section{Methods}

\section{Reagents}

Rabbit monoclonal anti-cyclin D1 was purchased from Neomarker (RM-9104-S1, Kalamazoo, MI, USA). Rabbit polyclonal anti-nNOS (sc-49055), anti-AIF (sc-9416), HRP (horseradish peroxidase)-conjugated goat-anti- 

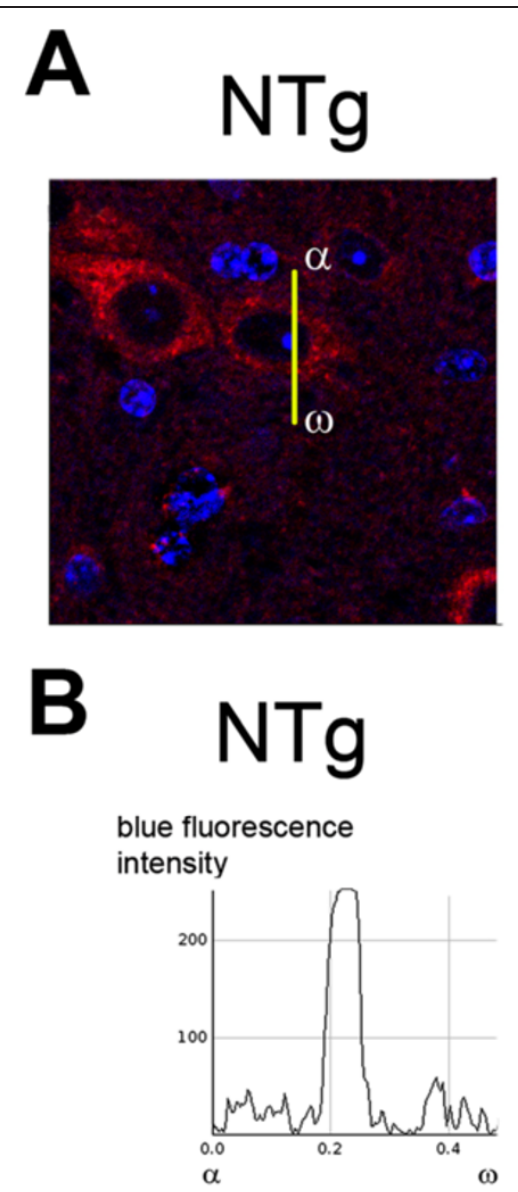

\section{red fluorescence intensity}

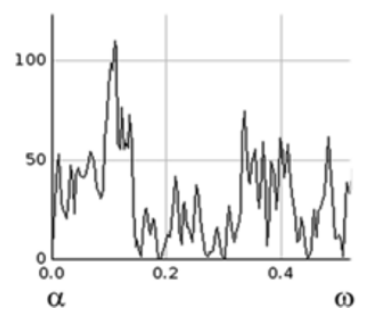

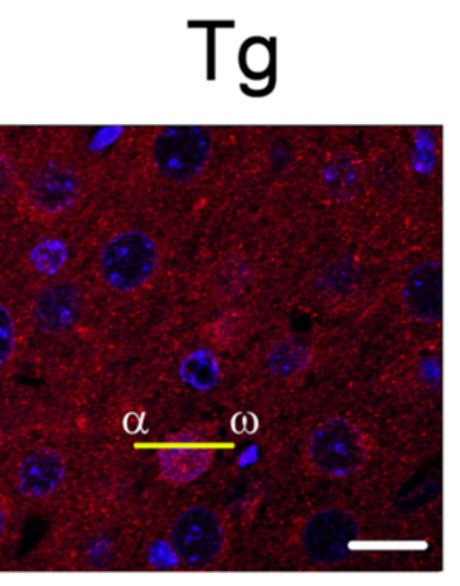

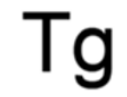

blue fluorescence intensity

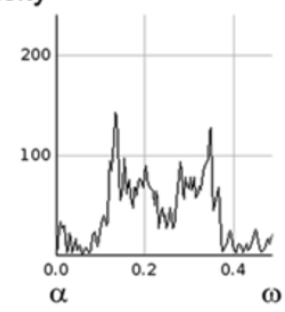

red fluorescence intensity

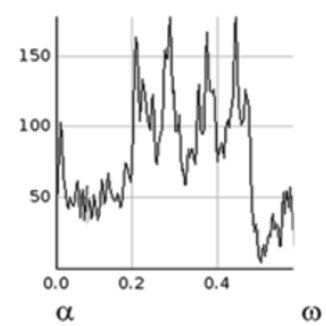

Figure 7 Confocal microscopy analysis of subcellular distribution of AIF in the cortex of Tg and non-Tg littermate mice shown at indicated ages. (A) Arrows point to the cells displaying the tAlF translocation to the nucleus which contrasts with the punctuate labelling in the cytoplasm reminiscent of mitochondrial localization. (B) The nuclear tranlocation of AlF was further analyzed by co-localization analysis of red and blue fluorescence corresponding to AIF and DAPI (used to stain the nuclei), respectively. Bar $=10 \mu \mathrm{m}$.

rabbit IgG (sc-2054), and HRP-conjugated anti- $\beta$-actine IgG (sc-47778 HRP) were obtained from Santa Cruz (Dallas, Texas, USA). Mouse monoclonal anti-Bax (556 467) was from BD Pharmingen (Qume Drive San Jose, CA, USA) whereas mouse monoclonal anti-cytochrome C (13575) and mouse monoclonal anti-COX IVb (110226) were from Abcam (Cambridge, MA, USA). Goat antirabbit IgGs conjugated with Alexa Fluor 568 used as a secondary antibody for immunocytochemistry was purchased from Jackson ImmunoResearch Laboratories (111-165-144,
West Grove, PA, USA). Rabbit polyclonal anti-GAPDH (G9545) and all other chemicals were from Sigma-Aldrich (Oakville, Ontario, Canada).

Animal breeding and $A \beta$ assays in brain tissue extracts The TgCRND8 mouse has been relatively well characterized and presents an advantage in developing AD-like pathology relatively fast. By the age of 3-4 months, these mice over-express human $A \beta$, encoded by a double mutated form of hAPP (695 (Swedish KM670/671NL and 
Indiana V717F APP mutations) transgene. Memory deficits and $A \beta$ pathology progress in the course of aging and from 6-7 months of age, these mice have a high $A \beta_{42} /$ $A \beta_{40}$ ratio and severe plaque load in many brain regions, including the hippocampus and cortex $[34,63]$.

All experiments using mice followed the policies and guidelines of the Canadian Council on Animal Care, the Animal Care regulations of the University of Toronto and of McGill University on the use of laboratory animals and the U.S. National Institutes of Health Guide for the Care and Use of Laboratory Animals. Efforts were always made to minimize the numbers of animals used and their distress. Sex-balanced groups of TgCR ND8 mice were maintained on an outbred C3H/C57BL6 background and kept on a $12 \mathrm{~h}$ light/dark cycle with food and water ad libitum. Four to 6 animals per experimental group were analyzed.

Brains from 2-, 4-, 6-7- and 9-month-old Tg and nontransgenic littermates (non- $\mathrm{Tg}$ ) were dissected on ice in order to retrieve the hippocampus, cortex (to assess the vulnerable areas) and cerebellum (chosen since it is relatively spared in $\mathrm{AD}$ ). Only $\mathrm{Tg}$ mice were analysed for total $A \beta$ using a formic acid extraction procedure. $A \beta_{1-}$ 42 and $A \beta_{1-40}$ content in dissected samples were quantified with commercially available sandwich ELISA kits (Invitrogen, Burlington, ON, Canada) as described previously [63].

\section{ATP content}

ATP content was determined in homogenates obtained from the studied brain regions by the high sensitivity ATP determination kit (Interchim, Montlucon Cedex, France) as per the manufacturer's instructions. Briefly, brain regions were homogenized in $1 \mathrm{mM}$ Tris-acetate buffer containing $2 \mathrm{mM}$ EDTA and $15 \mu \mathrm{g}$ of protein in brain homogenates was analysed. ATP disodium salt was used to prepare standard curves ranging from $10 \mathrm{nM}$ to $1 \mathrm{mM}$. Luminescence was quantified by Synergy 4 (Biotek, Winooski, VT, USA) at the emission wavelength of $560 \mathrm{~nm}$.

\section{Reactive Oxygen Species (ROS) quantification}

ROS was quantified by using the conversion of nonfluorescent Dichlorodihydrofluorescein Diacetate $\left(\mathrm{H}_{2} \mathrm{D}\right.$ CFDA) into the fluorescent $2^{\prime}, 7^{\prime}$-dichlorofluorescein (DCF) after cleavage by intracellular esterases and subsequent oxidation. In order to set up conditions for our assay, we optimized the protein concentration (50, 25 or $10 \mu \mathrm{g}$ ), incubation time ( $30 \mathrm{~min}, 3 \mathrm{~h}, 6 \mathrm{~h} 30,22 \mathrm{~h}$ and $24 \mathrm{~h}$ at $37^{\circ} \mathrm{C}$ ) and presence of $50 \mu \mathrm{M} \mathrm{H}_{2} \mathrm{O}_{2}$. These preliminary experiments (data not shown) allowed us to determine the following experimental conditions: $20 \mu \mathrm{g}$ of proteins per assay, $40 \mathrm{~min}$ incubation at $37^{\circ} \mathrm{C}$ and then addition of $50 \mu \mathrm{M} \mathrm{H}_{2} \mathrm{O}_{2}$, followed by 5 min incubation at room temperature. The brain region homogenates used for ROS quantification were prepared in RIPA buffer as previously reported [33]. The fluorescence was quantified at the excitation/emission wavelength of 485/ $530 \mathrm{~nm}$ (Synergy 4, Biotek, Winooski, VT, USA). ROS production was expressed as a ratio of the production determined for TgCRND8 over that found for non-Tg mice within an interval of less than three days of age in order to decrease the inter-mouse variability.

\section{Subcellular fractionation and Bax translocation assay}

Brain tissue was lysed in RIPA buffer $(20 \mathrm{mM}$ Tris- $\mathrm{HCl}$, pH 8.0, $150 \mathrm{mM} \mathrm{NaCl} 1 \mathrm{mM}$ EDTA, 1\% IgepalCA-630, $0.1 \%$ sodium dodecylsulfate (SDS), $50 \mathrm{mM} \mathrm{NaF}, 1 \mathrm{mM}$ NaVO3; $2 \mathrm{mM}$ phenylmethylsulfonyl fluoride, $10 \mu \mathrm{g} / \mathrm{ml}$ leupeptin, $50 \mu \mathrm{g} / \mathrm{ml}$ aprotinin) on ice for $30 \mathrm{~min}$. Cell lysates were centrifuged at $15,000 \times \mathrm{g}$ for $15 \mathrm{~min}$ at $4^{\circ} \mathrm{C}$ twice, and the resulting supernatant, representing the cytosolic fraction, was recovered. The mitochondrial fraction was isolated with the Mitochondria Isolation Kit. Briefly, the harvested cell pellet was suspended in isolation reagent $\mathrm{A}$ and incubated on ice for $2 \mathrm{~min}$, next the cell suspension was lysated in Dounce Tissue Grinder on ice, an equal volume of isolation reagent $C$ was added into the cell lysate and was mixed by inverting the tube several times. After centrifugation at $700 \times \mathrm{g}$ for $10 \mathrm{~min}$ at $4^{\circ} \mathrm{C}$, the supernatant was further centrifuged at $12,000 \times \mathrm{g}$ for $15 \mathrm{~min}$ at $4^{\circ} \mathrm{C}$. The pellet containing the isolated mitochondria was re-suspended in RIPA buffer.

After western blot assessment (see below), the percentage of mitochondrial Bax translocation was calculated as a fraction of Bax probed in mitochondrial fraction out of total Bax (Bax probed in the mitochondrial fraction + Bax probed in the cytoplasmic fraction). The relative quantities of Bax were determined as a ratio of R.O.D measured for Bax in each cellular fraction after normalization over COX IVb and GAPDH for mitochondrial and cytoplasmic fractions, respectively. To allow the comparison between ages, the percentage of Bax translocated to mitochondria in TgCRND8 mice was normalized over the perceentage of Bax translocated to mitochondria in non-transgenic animals taken as a reference (100\%).

\section{Western blot quantification}

Protein extracts were prepared by using RIPA buffer extraction as previously reported [33]. Briefly, $40 \mu \mathrm{g}$ of total proteins, diluted in Laemli buffer (Sigma-Aldrich, Oakville, Ontario, Canada), were boiled for $5 \mathrm{~min}$ and then separated by SDS-PAGE, on a Tris-Glycine 4-20\% gradient gel (Invitrogen, Burlington, ON, Canada), at $130 \mathrm{~V}$ for $2 \mathrm{k} / 2 \mathrm{~h}$. Proteins were transferred to nitrocellulose membranes at $80 \mathrm{~V}$ for $45 \mathrm{~min}$ at $4^{\circ} \mathrm{C}$, under agitation. Membranes were incubated with 5\% skim milk diluted in Tris-buffered saline (TBS) containing 0.05\% Tween (TBS-T) for $1 \mathrm{~h}$ at room temperature and then 
incubated with primary antibodies overnight at $4^{\circ} \mathrm{C}$ in $1 \%$ skim milk diluted in TBS-T. Three washes of $5 \mathrm{~min}$ in TBS-T were performed and then secondary antibodies were incubated for $1 \mathrm{~h}$ at room temperature in $1 \%$ milk TBS-T. After washings, the following primary antibodies were used: anti-nNOS (1:1000), anti-AIF (1: 5000), anticyclin D1 and anti-Bax (both in 1:500 dilution). The HRP-conjugated goat-anti-rabbit IgG was applied as a secondary antibody in parallel with the HRP-conjugated anti$\beta$-actin IgG (both in 1:5000 dilution), used as an internal standard for equal loading. Visualization was performed using Western lightning chemiluminescence Reagent Plus kit (Perkin-Elmer, Waltham, MA, USA). Densitometric analysis of the immunoreactive bands was performed using Scion Image software (Scion Corporation, Frederick, MA, USA). The optical density (OD) measured for each immune-reactive band was normalized to $\beta$-actin. In agreement with our previous study of normal rat brain aging [33], AIF expression was relatively stable for each studied brain region in the course of non-Tg aging. Relevant AIF expression in non-Tg mice was therefore taken as a reference and results were expressed as the ratio of the values calculated for transgenic over the non-Tg mice analyzed on the same films and expressed as relative optical density (R.O.D).

\section{Immunohistochemistry of AIF-immunoreactive neurons in Tg mice and their non-Tg littermates}

Transgenic and non-Tg littermates (age-matched at 2, 4, 6-7 and 9 months) were transcardially perfused with cold PBS-heparin and their brains isolated, post-fixed in formaldehyde and embedded in paraffin [47], and after slicing into $8 \mu \mathrm{m}$-thick coronal sections, immunohistochemistry proceeded. Briefly, sections were first incubated with $10 \%$ normal goat serum (NGS) in $0.05 \mathrm{M}$ TBS for $1 \mathrm{hr}$ at RT. For antigen retrieval, sections were incubated in $0.05 \mathrm{M}$ citrate-buffered saline $\left(\mathrm{pH} \mathrm{6.0)}\right.$ for $10 \mathrm{~min}$ at $95^{\circ} \mathrm{C}$. Primary incubation followed overnight at $4^{\circ} \mathrm{C}$ with anti-AIF antibody in TBS (1:300 dilution). Subsequently, sections were incubated for $1 \mathrm{hr}$ at RT with goat anti-rabbit IgGs conjugated with Alexa Fluor 568 (1:200) and then incubated with DAPI $(2 \mu \mathrm{g} / \mathrm{ml})$ for $30 \mathrm{~min}$ at RT. Sections were washed in TBS $(3 \times 5 \mathrm{~min})$ between incubations. AIF immunoreactivity (AIF-ir) was labelled in red and nuclei in blue.

\section{Statistical analysis}

GraphPad Prism 5 (GraphPad Software, San Diego, CA) or IBM SPSS Statistics 20 was used for statistical analyses. Independent $\mathrm{t}$-tests were used to compare the mean group values. The mean values of three or more groups were compared with one- or two-way ANOVA and NeumanKeuls' post-test. In all cases, significance was noted at $\mathrm{p}<0.05^{(*)}, \mathrm{p}<0.01{ }^{(* *)}, \mathrm{p}<0.001{ }^{(* * *)}$. Figures were prepared with Adobe Photoshop CS4 Extended, version 11.0 (Adobe Systems Inc., San Jose, CA).

\section{Competing interests}

The authors declare that they have no competing interests.

\section{Authors' contributions}

WY did the tissue microdissection, carried out western blot, immunohistochemical studies and participated in the writing of the first version of the manuscript; MB carried out ATP and ROS detection studies and analyzed the relevant data; MF did some western blot experiments, analyzed the relevant data and prepared the figures; KM performed ELISA and statistical analysis; JGC was in charge of animal breeding and genotyping; EM participated in immunohistochemical experiments; JM participated in the design and significantly contributed to the elaboration of the study; SK and RQ conceived the study and coordinated it's realization; SK and WY wrote the first draft; AT performed confocal microscopy analysis and participated in the preparation of the figures and with ZG drafted the final version of the MS; all authors read and approved the manuscript.

\section{Acknowledgments}

The authors warmly thank Mrs Mary Brown for her precious technical help. We also acknowledge the technical help from Miss Justine Boursier during the initial phase of this study. This research was supported by CIHR operating grant to RQ (MOP-8580), joint INSERM/FRSQ cooperation program to SK (France) and RQ (Quebec), Alzheimer's Society of Canada Research Grant (JM) and Fellowship (KM), International cooperation grant of Guizhou Science and Technology Department to WY (G-2013-7026).

\section{Author details}

${ }^{1}$ Key laboratory of Molecular Biology, Guiyang Medical University, Guiyang 550004, China. ${ }^{2}$ Department of Psychiatry, Douglas Mental Health University Institute (DMHUI), McGill University, Verdun Montréal, Québec H4H 1R3, Canada. ${ }^{3}$ Department Laboratory Medicine and Pathobiology, Faculty of Medicine, University of Toronto, Toronto, Ontario M5S 1A8, Canada. ${ }^{4}$ Centre de Recherche des Cordeliers, UMRS872, Paris, France. ${ }^{5}$ Department of Pathology in the Affiliated Hospital of Guiyang Medical University, Guiyang 550004, China

Received: 24 April 2014 Accepted: 30 May 2014

Published: 10 June 2014

\section{References}

1. Hardy J, Allsop D: Amyloid deposition as the central event in the aetiology of Alzheimer's disease. Trends Pharmacol Sci 1991, 12:383-388.

2. Selkoe DJ: The molecular pathology of Alzheimer's disease. Neuron 1991 6:487-498

3. Bellucci A, Luccarini I, Scali C, Prosperi C, Giovannini MG, Pepeu G, Casamenti F: Cholinergic dysfunction, neuronal damage and axonal loss in TgCRND8 mice. Neurobiol Dis 2006, 23:260-272.

4. Ramos B, Baglietto-Vargas D, del Rio JC, Moreno-Gonzalez I, Santa-Maria C, Jimenez S, Caballero C, Lopez-Tellez JF, Khan ZU, Ruano D, Gutierrez A, Vitorica J: Early neuropathology of somatostatin/NPY GABAergic cells in the hippocampus of a PS1XAPP transgenic model of Alzheimer's disease. Neurobiol Aging 2006, 27:1658-1672.

5. Schmitz C, Rutten BP, Pielen A, Schafer S, Wirths O, Tremp G, Czech C, Blanchard V, Multhaup G, Rezaie P, Korr H, Steinbusch HW, Pradier L, Bayer TA: Hippocampal neuron loss exceeds amyloid plaque load in a transgenic mouse model of Alzheimer's disease. Am J Pathol 2004 164:1495-1502.

6. Marx J: Neuroscience. New leads on the 'how' of Alzheimer's. Science 2001, 293:2192-2194.

7. Mattson MP: Apoptosis in neurodegenerative disorders. Nat Rev Mol Cell Biol 2000, 1:120-129.

8. LeBlanc AC: The role of apoptotic pathways in Alzheimer's disease neurodegeneration and cell death. Curr Alzheimer Res 2005, 2:389-402.

9. Chung CW, Song YH, Kim IK, Yoon WJ, Ryu BR, Jo DG, Woo HN, Kwon YK,

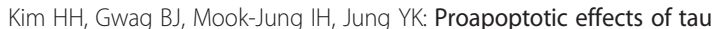
cleavage product generated by caspase-3. Neurobiol Dis 2001, 8:162-172.

10. Gamblin TC, Chen F, Zambrano A, Abraha A, Lagalwar S, Guillozet AL, Lu M, Fu Y, Garcia-Sierra F, LaPointe N, Miller R, Berry RW, Binder LI, Cryns VL: 
Caspase cleavage of tau: linking amyloid and neurofibrillary tangles in Alzheimer's disease. Proc Natl Acad Sci U S A 2003, 100:10032-10037.

11. Gervais FG, Xu D, Robertson GS, Vaillancourt JP, Zhu Y, Huang J, LeBlanc A, Smith D, Rigby M, Shearman MS Clarke EE, Zheng H, Van Der Ploeg LH, Ruffolo SC, Thornberry NA, Xanthoudakis S, Zamboni RJ, Roy S, Nicholson DW: Involvement of caspases in proteolytic cleavage of Alzheimer's amyloid-beta precursor protein and amyloidogenic $A$ beta peptide formation. Cell 1999, 97:395-406.

12. Guo H, Albrecht S, Bourdeau M, Petzke T, Bergeron C, LeBlanc AC: Active caspase- 6 and caspase-6-cleaved tau in neuropil threads, neuritic plaques, and neurofibrillary tangles of Alzheimer's disease. Am J Pathol 2004, 165:523-531.

13. Lu DC, Rabizadeh S, Chandra S, Shayya RF, Ellerby LM, Ye X, Salvesen GS, Koo EH, Bredesen DE: A second cytotoxic proteolytic peptide derived from amyloid beta-protein precursor. Nat Med 2000, 6:397-404.

14. Rohn TT, Head E, Nesse WH, Cotman CW, Cribbs DH: Activation of caspase-8 in the Alzheimer's disease brain. Neurobiol Dis 2001, 8:1006-1016.

15. Rohn TT, Rissman RA, Davis MC, Kim YE, Cotman CW, Head E: Caspase-9 activation and caspase cleavage of tau in the Alzheimer's disease brain. Neurobiol Dis 2002, 11:341-354.

16. Cregan SP, Fortin A, MacLaurin JG, Callaghan SM, Cecconi F, Yu SW, Dawson TM, Dawson VL, Park DS, Kroemer G, Slack RS: Apoptosis-inducing factor is involved in the regulation of caspase-independent neuronal cell death. J Cell Biol 2002, 158:507-517.

17. Krantic S, Mechawar N, Reix S, Quirion R: Apoptosis-inducing factor: a matter of neuron life and death. Prog Neurobiol 2007, 81:179-196.

18. Lankiewicz S, Marc Luetjens C, Truc Bui N, Krohn AJ, Poppe M, Cole GM, Saido TC, Prehn JH: Activation of calpain I converts excitotoxic neuron death into a caspase-independent cell death. J Biol Chem 2000, 275:17064-17071.

19. Joza N, Susin SA, Daugas E, Stanford WL, Cho SK, Li CY, Sasaki T, Elia AJ, Cheng HY, Ravagnan L, Ferri KF, Zamzami N, Wakeham A, Hakem R, Yoshida H, Kong YY, Mak TW, Zúñiga-Pflücker JC, Kroemer G, Penninger JM: Essential role of the mitochondrial apoptosis-inducing factor in programmed cell death. Nature 2001, 410:549-554.

20. Susin SA, Lorenzo HK, Zamzami N, Marzo I, Snow BE, Brothers GM, Mangion J, Jacotot E, Costantini P, Loeffler M, Larochette N, Goodlett DR, Aebersold R, Siderovski DP, Penninger JM, Kroemer G: Molecular characterization of mitochondrial apoptosis-inducing factor. Nature 1999, 397:441-446.

21. Wang H, Yu SW, Koh DW, Lew J, Coombs C, Bowers W, Federoff HJ, Poirier GG, Dawson TM, Dawson VL: Apoptosis-inducing factor substitutes for caspase executioners in NMDA-triggered excitotoxic neuronal death. J Neurosci 2004, 24:10963-10973.

22. Yu W, Mechawar N, Krantic S, Quirion R: Evidence for the involvement of apoptosis-inducing factor-mediated caspase-independent neuronal death in Alzheimer disease. Am J Pathol 2010, 176:2209-2218.

23. Urbano A, Lakshmanan U, Choo PH, Kwan JC, Ng PY, Guo K, Dhakshinamoorthy S, Porter A: AIF suppresses chemical stress-induced apoptosis and maintains the transformed state of tumor cells. EMBO J 2005, 24:2815-2826.

24. Vahsen N, Cande C, Briere JJ, Benit P, Joza N, Larochette N, Mastroberardino PG, Pequignot MO, Casares N, Lazar V, Feraud O, Debili N, Wissing S, Engelhardt S, Madeo F, Piacentini M, Penninger JM, Schägger $H$, Rustin P, Kroemer G: AIF deficiency compromises oxidative phosphorylation. EMBO J 2004, 23:4679-4689.

25. Polster BM, Basanez G, Etxebarria A, Hardwick JM, Nicholls DG: Calpain I induces cleavage and release of apoptosis-inducing factor from isolated mitochondria. J Biol Chem 2005, 280:6447-6454

26. Yuste VJ, Moubarak RS, Delettre C, Bras M, Sancho P, Robert N, D'Alayer J, Susin SA: Cysteine protease inhibition prevents mitochondrial apoptosisinducing factor (AIF) release. Cell Death Differ 2005, 12:1445-1448.

27. Artus C, Boujrad H, Bouharrour A, Brunelle MN, Hoos S, Yuste VJ, Lenormand P, Rousselle JC, Namane A, England P, Lorenzo HK, Susin SA: AIF promotes chromatinolysis and caspase-independent programmed necrosis by interacting with histone H2AX. EMBO J 2010, 29:1585-1599.

28. Moubarak RS, Yuste VJ, Artus C, Bouharrour A, Greer PA, Menissier-De Murcia J, Susin SA: Sequential activation of poly (ADP-ribose) polymerase 1, calpains, and Bax is essential in apoptosis-inducing factor-mediated programmed necrosis. Mol Cell Biol 2007, 27:4844-4862.

29. Yuste VJ, Sanchez-Lopez I, Sole C, Moubarak RS, Bayascas JR, Dolcet X, Encinas M, Susin SA, Comella JX: The contribution of apoptosis-inducing factor, caspase-activated DNase, and inhibitor of caspase-activated DNase to the nuclear phenotype and DNA degradation during apoptosis. J Biol Chem 2005, 280:35670-35683.

30. Klein JA, Ackerman SL: Oxidative stress, cell cycle, and neurodegeneration. J Clin Invest 2003, 111:785-793.

31. Klein JA, Longo-Guess CM, Rossmann MP, Seburn KL, Hurd RE, Frankel WN, Bronson RT, Ackerman SL: The harlequin mouse mutation downregulates apoptosis-inducing factor. Nature 2002, 419:367-374.

32. El Ghouzzi V, Csaba Z, Olivier P, Lelouvier B, Schwendimann L, Dournaud P, Verney C, Rustin P, Gressens P: Apoptosis-inducing factor deficiency induces early mitochondrial degeneration in brain followed by progressive multifocal neuropathology. I Neuropathol Exp Neurol 2007, 66:838-847.

33. Yu W, Gubkina O, Mechawar N, Elwell D, Quirion R, Krantic S: Expression of apoptosis-inducing factor (AIF) in the aged rat brain. Neurobiol Aging 2011, 32:179-180.

34. Chishti MA, Yang DS, Janus C, Phinney AL, Horne P, Pearson J, Strome R, Zuker N, Loukides J, French J, Turner S, Lozza G, Grilli M, Kunicki S, Morissette C, Paquette J, Gervais F, Bergeron C, Fraser PE, Carlson GA, George-Hyslop PS, Westaway D: Early-onset amyloid deposition and cognitive deficits in transgenic mice expressing a double mutant form of amyloid precursor protein 695. J Biol Chem 2001, 276:21562-21570.

35. Salek RM, Xia J, Innes A, Sweatman BC, Adalbert R, Randle S, McGowan E, Emson PC, Griffin JL: A metabolomic study of the CRND8 transgenic mouse model of Alzheimer's disease. Neurochem Int 2010, 56:937-947.

36. Kudo W, Lee HP, Smith MA, Zhu X, Matsuyama S, Lee HG: Inhibition of Bax protects neuronal cells from oligomeric Abeta neurotoxicity. Cell Death Dis 2012, 3:e309.

37. Dodart JC, Mathis C, Bales KR, Paul SM: Does my mouse have Alzheimer's disease? Genes Brain Behav 2002, 1:142-155

38. Duyckaerts C, Potier MC, Delatour B: Alzheimer disease models and human neuropathology: similarities and differences. Acta Neuropathol 2008, 115:5-38.

39. Janus C, Westaway D: Transgenic mouse models of Alzheimer's disease. Physiol Behav 2001, 73:873-886.

40. Krantic S, Isorce N, Mechawar N, Davoli MA, Vignault E, Albuquerque M, Chabot JG, Moyse E, Chauvin JP, Aubert I, McLaurin J, Quirion R: Hippocampal GABAergic neurons are susceptible to amyloid-beta toxicity in vitro and are decreased in number in the Alzheimer's disease TgCRND8 mouse model. J Alzheimers Dis 2012, 29:293-308.

41. Renault TT, Manon S: Bax: Addressed to kill. Biochimie 2011, 93:1379-1391.

42. Renault TT, Chipuk JE: Death upon a kiss: mitochondrial outer membrane composition and organelle communication govern sensitivity to BAK/ BAX-dependent apoptosis. Chem Biol 2014, 21:114-123.

43. Butterfield DA: Amyloid beta-peptide (1-42)-induced oxidative stress and neurotoxicity: implications for neurodegeneration in Alzheimer's disease brain. A review. Free Radic Res 2002, 36:1307-1313.

44. Nguyen D, Alavi MV, Kim KY, Kang T, Scott RT, Noh YH, Lindsey JD, Wissinger B, Ellisman MH, Weinreb RN, Perkins GA, Ju WK: A new vicious cycle involving glutamate excitotoxicity, oxidative stress and mitochondrial dynamics. Cell Death Dis 2011, 2:e240

45. Efthimiadi L, Farso M, Quirion R, Krantic S: Cyclin D1 induction preceding neuronal death via the excitotoxic NMDA pathway involves selective stimulation of extrasynaptic NMDA receptors and JNK pathway. Neurodegener Dis 2012, 10:80-91.

46. Hardingham GE, Bading H: Synaptic versus extrasynaptic NMDA receptor signalling: implications for neurodegenerative disorders. Nat Rev Neurosci 2010, 11:682-696

47. Malik B, Currais A, Soriano S: Cell cycle-driven neuronal apoptosis specifically linked to amyloid peptide Abeta1-42 exposure is not exacerbated in a mouse model of presenilin-1 familial Alzheimer's disease. J Neurochem 2008, 106:912-916.

48. Wu Q, Combs C, Cannady SB, Geldmacher DS, Herrup K: Beta-amyloid activated microglia induce cell cycling and cell death in cultured cortical neurons. Neurobiol Aging 2000, 21:797-806.

49. Hoozemans JJ, Bruckner MK, Rozemuller AJ, Veerhuis R, Eikelenboom P, Arendt T: Cyclin D1 and cyclin E are co-localized with cyclo-oxygenase 2 (COX-2) in pyramidal neurons in Alzheimer disease temporal cortex. J Neuropathol Exp Neurol 2002, 61:678-688.

50. Malik B, Currais A, Andres A, Towlson C, Pitsi D, Nunes A, Niblock M, Cooper J, Hortobagyi T, Soriano S: Loss of neuronal cell cycle control as a mechanism of neurodegeneration in the presenilin-1 Alzheimer's disease brain. Cell Cycle 2008, 7:637-646. 
51. Yang Y, Herrup K: Cell division in the CNS: protective response or lethal event in post-mitotic neurons? Biochim Biophys Acta 2007, 1772:457-466.

52. Chou JL, Shenoy DV, Thomas N, Choudhary PK, Laferla FM, Goodman SR, Breen GA: Early dysregulation of the mitochondrial proteome in a mouse model of Alzheimer's disease. J Proteomics 2011, 74:466-479.

53. Hamilton $A$, Holscher $C$ : The effect of ageing on neurogenesis and oxidative stress in the APP (swe)/PS1 (deltaE9) mouse model of Alzheimer's disease. Brain Res 2012, 1449:83-93.

54. Hauptmann S, Scherping I, Drose S, Brandt U, Schulz KL, Jendrach M, Leuner K, Eckert A, Muller WE: Mitochondrial dysfunction: an early event in Alzheimer pathology accumulates with age in AD transgenic mice. Neurobiol Aging 2009, 30:1574-1586.

55. Lee SH, Kim KR, Ryu SY, Son S, Hong HS, Mook-Jung I, Ho WK: Impaired short-term plasticity in mossy fiber synapses caused by mitochondrial dysfunction of dentate granule cells is the earliest synaptic deficit in a mouse model of Alzheimer's disease. J Neurosci 2012, 32:5953-5963.

56. Reddy PH, McWeeney S, Park BS, Manczak M, Gutala RV, Partovi D, Jung Y, Yau V, Searles R, Mori M, Quinn J: Gene expression profiles of transcripts in amyloid precursor protein transgenic mice: up-regulation of mitochondrial metabolism and apoptotic genes is an early cellular change in Alzheimer's disease. Hum Mol Genet 2004, 13:1225-1240.

57. Kuzyk A, Kastyak M, Agrawal V, Gallant M, Sivakumar G, Rak M, Del Bigio MR, Westaway D, Julian R, Gough KM: Association among amyloid plaque, lipid, and creatine in hippocampus of TgCRND8 mouse model for Alzheimer disease. J Biol Chem 2010, 285:31202-31207.

58. Yang DS, Kumar A, Stavrides P, Peterson J, Peterhoff CM, Pawlik M, Levy E, Cataldo AM, Nixon RA: Neuronal apoptosis and autophagy cross talk in aging PS/APP mice, a model of Alzheimer's disease. Am J Pathol 2008, 173:665-681.

59. Cimini A, Moreno S, D'Amelio M, Cristiano L, D'Angelo B, Falone S, Benedetti E, Carrara P, Fanelli F, Cecconi F, Amicarelli F, Cerù MP: Early biochemical and morphological modifications in the brain of a transgenic mouse model of Alzheimer's disease: a role for peroxisomes. J Alzheimers Dis 2009, 18:935-952.

60. Fenili D, Weng YQ, Aubert I, Nitz M, McLaurin J: Sodium/myo-Inositol transporters: substrate transport requirements and regional brain expression in the TgCRND8 mouse model of amyloid pathology. PLoS One 2011, 6:e24032

61. Chinta SJ, Rane A, Yadava N, Andersen JK, Nicholls DG, Polster BM: Reactive oxygen species regulation by AIF- and complex I-depleted brain mitochondria. Free Radic Biol Med 2009, 46:939-947.

62. Gartner U, Bruckner MK, Krug S, Schmetsdorf S, Staufenbiel M, Arendt T: Amyloid deposition in APP23 mice is associated with the expression of cyclins in astrocytes but not in neurons. Acta Neuropathol 2003, 106:535-544.

63. Ma K, Mount HT, McLaurin J: Region-specific distribution of beta-amyloid peptide and cytokine expression in TgCRND8 mice. Neurosci Lett 2011, 492:5-10.

doi:10.1186/1471-2202-15-73

Cite this article as: Yu et al:: The expression of apoptosis inducing factor (AIF) is associated with aging-related cell death in the cortex but not in the hippocampus in the TgCRND8 mouse model of Alzheimer's disease. BMC Neuroscience 2014 15:73.

\section{Submit your next manuscript to BioMed Central and take full advantage of:}

- Convenient online submission

- Thorough peer review

- No space constraints or color figure charges

- Immediate publication on acceptance

- Inclusion in PubMed, CAS, Scopus and Google Scholar

- Research which is freely available for redistribution

Submit your manuscript at www.biomedcentral.com/submit
C Biomed Central 